\title{
Evaluation of Good Governance Principles Implementation Using Polling Data
}

\author{
Olena Akimova \\ Dept. of Theory and Practice of Management, Igor Sikorsky Kyiv Polytechnic Institute \\ 03056, Kyiv Peremohy Ave.37, Ukraine \\ E-mail: olena.kasatkina@gmail.com
}

Anna Ishchenko

Dept. of Theory and Practice of Management, Igor Sikorsky Kyiv Polytechnic Institute 03056, Kyiv Peremohy Ave.37, Ukraine

E-mail: ishchenko.kpi@gmail.com

\begin{abstract}
Anatolii Melnychenko
Dept. of Theory and Practice of Management, Igor Sikorsky Kyiv Polytechnic Institute 03056, Kyiv Peremohy Ave.37, Ukraine

E-mail: anatolii.melnychenko@gmail.com
\end{abstract}

Received: Nov. 10, 2019 Accepted: Dec. 5, 2019 Online published: Dec. 22, 2019

doi:10.5296/jpag.v9i4.15784 URL: https://doi.org/10.5296/jpag.v9i4.15784

\begin{abstract}
The article deals with the peculiarities of polling data application in evaluating public authorities' adherence to the good governance principles. Opportunities and threats of soft and polling data implementation are highlighted considering the possible interests of the main stakeholders of the governance process. Evaluation of 12 good governance principles realization on public opinion basis has been analyzed, while the most relevant methods of raw data collecting have been identified, taking into account the peculiarities of main target audiences: citizens, civil servants and civil society organizations representatives.
\end{abstract}

Keywords: good governance, governance efficiency, soft data, polling data 


\section{Introduction}

The implementation of good governance principles requires decision-makers to use a number of tools to measure the real configuration of efficiency and quality of state services. This toolkit should be designed in order to identify the advantages and disadvantages of the chosen strategy of particular governance practices implementation that have been proven in different countries. However, commonly used universal measurement tools (such as The World Governance Index, E-Government Development Index, Sustainable Governance Indicators and others) have a number of limitations, although they allow to conduct a comparative analysis of good governance development level in a wide range of countries and regions. However, this kind of measure tools has its logical limitations, which is due not only to the fact that different countries use different practices of raw data collection and processing, or because of the subjectiveness of widely used expert judgments. These limitations are largely caused by the predominant use of purely statistical observations (such as the number of public servants, number of administration service centers). These techniques provide an opportunity to analyze development trends, compare countries, but often do not work to identify the root causes of recorded trends (both factors that impede the implementation of good governance principles and those that activate it).

Taking into account nothing but statistical indicators it is impossible to reveal the in-depth motives that relate to the direct behavior of the main actors responsible for implementing reforms at all levels of government. It is also important to recognize that people have different expectations and face different problems with regard to public administration, depending on their place of residence and gender, ethnicity, knowledge and personal experience, as it argues in UNDP Guidance Note for Assessing Rule of Law in Public Administration ("Guidance Note for Assessing Rule of Law in Public Administration", 2015). Thus, measuring the adherence level to the principles of good governance requires the use of so-called soft data.

\section{Literature Review}

The concept of good governance, first used in 1992 at the The Annual World Bank Conference on Development Economics, is still relevant today. Numerous scientific papers are devoted to studies of the role of this governance model in involving the public in the process of exercising a public power, improving the efficiency of the whole system of public administration, development of civil society, political culture of citizens, etc. The role of good governance in achieving balanced socio-economic development has been explored by Berger (2003), Kaufman (2006), Wijkman (1998), Graham (2003), Stojanovic et al. (2016) and others. At the same time this concept has recently become more relevant in developing countries. And the study of government model transformation in such countries is reflected in the works of Danylyshyn (2016), Bangura, \& Larbi (2006), den Heyer (2011), Shpachuk (2019) and others.

One can define a wide range of mechanisms and algorithms to measure the successes and failures of managerial process on the level of the state. A significant part of them were studied both by researchers in public administration and by sociologists. So, cognitive 
potential of evaluation indexes in public administration and a wide range of good governance rankings were critically studied by Besancon (2003), Tampieri (2014), Arndt and Oman (2006) etc. Essentially they demonstrate the predominance of "hard" data (mostly statistical data) usage. Among the most popular governance efficiency ranking tools we can define:

- World Bank Governance Surveys: country-level management assessment tools that use information collected from country, business and public sector citizens to diagnose management vulnerabilities.

- The World Governance Index (WGI): use of comprehensive indexes such as peace and security, rule of law, human rights and participation, sustainable development and human development.

- Sustainable Governance Indicators (SGIs): systematic measurement of reform needs and capacity to reform within (OECD) countries.

- A wide range of regional integrated indicators, in particular the European Quality of Government Index (EQI), the Mo Ibrahim Foundation's Ibrahim Index, which ranks 53 African countries in 84 categories, and so on.

While sociological understanding of governance efficiency measurement was studied by Garbarino and Holland (2009), Rochefort, and Boyer (1988), Petry and Birch (2011) etc. A substantial number of studies were held to define the best proportion between "qualitative" and "quantitative" paradigms in governance successfulness evaluation. The study presented in the article is devoted to the consideration of the problems and limitations of 12 principles of good governance implementation measurement, in particular potentialities of "soft" data usage (for example, sociological tools and polling data) in order to measure the extent to which local authorities comply with principles mentioned above. So, the aim of the study is to explore the cognitive potential of polling data for measuring the extent to which local governments comply with good governance principles, options of governance effectiveness evaluation involving a sociological toolkit designed to interview ordinary citizens, as well as implementation policies influence agents.

\section{Problem Analysis}

The implementation of a citizen-centered approach to public service delivery is a sine qua non of modern public administration paradigm It creates and maintains a level of dialogue and trust between the citizen and the government. According to a study of Sharma and Rathore (2020), the introduction of such a system contributes to increased public satisfaction and reduced public costs.

Good Governance is a public administration modernization concept that has been widely used in conjunction with the alternative new public management (NPM) concept. The principles of good democratic governance at the local level are as follows ("12 Principles of Good Governance", n.d.):

1. Participation, Representation, Fair Conduct of Elections 
2. Responsiveness

3. Efficiency and Effectiveness

4. Openness and Transparency

5. Rule of Law

6. Ethical Conduct

7. Competence and Capacity

8. Innovation and Openness to Change

9. Sustainability and Long-Term Orientation

10. Sound Financial Management

\section{Human Rights, Cultural Diversity and Social Cohesion}

12. Accountability.

Unlike new public management (NPM), this model of public administration means "close cooperation between the state, business and civil society, which focuses on partnerships, where politicians and public officials make decisions together with civil society. This model is aimed at overcoming the shortcomings of the NPM, such as the sideline of solving social problems and increasing the level of social inequality and poverty, reducing the role of the state and public servants in public relations" (Vorobyova, 2015, p. 232). Thus, this concept redefines the role of the state in regulating of key socio-economic processes, emphasizing that it is the state (and therefore the public authorities) that should become the arbiter, not the governor or outsider. With respect to the need to develop a strategy for the implementation of this concept in each country, the above mentioned principles have been proposed, the adherence to which is a guarantee of the implementation of the concept of good governance in certain country. However, it is not enough to proclaim these principles without creating valid evaluation mechanisms of their implementation effectiveness.

The use of so-called soft data to support research in public administration, as well as to determine the effectiveness of good governance principles implementation, is based on the basic functions of applied sociology. Any study of social life is based on the knowledge that is already developed by somebody. Using this kind of data allows us to compare it with our own judgments, conclusions, and knowledge of our predecessors. Benchmarking of "old" and "new" conclusions leads to several variants of theoretical understanding. For example, new data obtained during a sociological survey is logically explained, fully fit into existing data. Or another situation: explaining the information obtained requires the introduction of new concepts and categories, as they cannot be explained within the framework of existing theories. Developing new concepts that evaluate new phenomena of social reality is the most important task of scientific reflection. It not only develops its own exploration area (in our case, the sphere of public administration), but also improves methods and techniques of applied data collection. 
The idea of polling data use in order to measure compliance is not new. In particular, it was admitted by Ivanyna and Shah (2011) that the distinction of governance institutions requires deeper analytical work through in-depth comparative research rather than aggregate indicators. Such metrics are more useful for comparing management outcomes, and additional analytical studies of institutions and processes can be used to explain different outcomes. Of course, managerial outcomes assume generally accepted values, but this is comparatively less problematic than unambiguous prescriptions for all processes. Kaufmann and Kray argue that all measures of governance involve a degree of subjective judgment, and different levels of aggregation are appropriate for different types of analysis (Kaufmann, Kraay, 2008, p.3). Therefore "soft" subjective data can be crucial in order to determine the difference between de jure and de facto of institutional mechanisms. For this reason, the Council of Europe has recently proposed to use a set of questionnaires designed for specific target audiences in local authorities' practices. In order to facilitate the full implementation of good governance principles and to monitor the process of their implementation, the Council of Europe has developed and proposed to its Member States (Huk, 2018):

- Constituents of the principle - a description of the activities enabling the provisions of each principle to be more fully implemented;

- Indicators to assess the degree of implementation of the constituents of the principle against current best practices;

- Questionnaires for community representatives and local governments to measure the value of the indicators. These tools have formed the basis for good governance benchmarking.

In particular, questionnaires were offered for local government officials and / or members of local councils, as well as for the population and / or representatives of civil society organizations (Huk, 2018, p.28). However, if some of the questionnaires developed for so-called quasi-expert polls (for example, questionnaires for community representatives and local governments) can provide relevant questionnaires, then copying of this methodology in the survey among ordinary citizens in certain parts requires additional operationalization (the process of moving from general theoretical concepts of the study to specific empirical indicators that are understandable for the object of the study). The authors note that the questionnaire for the public / civil society organization contains a formulation of good governance principles for the purpose of the questionnaire. And, indeed, this technique was developed using the basic criteria of sociological information quality (for example, criteria of validity and reliability). In particular, the principle of good governance - fair elections, representation and participation as a guarantee of a real opportunity for every resident of the community to have the right to vote in social and political life at the local level - has been operationalized through a valid value "satisfaction with the opportunities that citizens have to influence the decisions of local government bodies".

Nevertheless, it is necessary to develop other possible options for improving the toolkit for good governance measuring. For example, evaluating of the implementation of the principle "sustainable development and strategic orientation - to take into account the interests of future generations" needs to be improved. In particular, the concept of "sustainable 


\section{Macrothink}

development" is part of a theory that may not always be understood (or correctly interpreted) by an average citizen, even if it adheres to his or her basic principles in everyday life. Therefore, the measurement by questionnaires of the implementation of this principle by the local self-government requires mandatory operationalization.

Referring to the list of Sustainable Development Goals officially approved by the UN General Assembly at the end of September 2015, each of them can be selected as an element of operationalization. However, given the obvious resource constraints on conducting such surveys, we consider it appropriate to select the ones that are most relevant (most important) to the certain community, region or country. In particular, the 16th Sustainable Development Goal "Promote peaceful and inclusive societies for sustainable development, provide access to justice for all and build effective, accountable and inclusive institutions at all levels", which has recently become especially relevant in countries with ongoing armed conflicts (such as Colombia, Venezuela, Ukraine etc.) cannot be ignored as an indicator of sustainability in the areas most closely related to combat sites (for example, in regions of eastern Ukraine).

Despite a number of limitations, use of polling data in good governance evaluation provides additional cognitive opportunities for researchers. First and foremost, this data once obtained (taking into account its source: citizen, public manager or public sector representative) can be correlated with a number of relevant features in terms of the study results. It is not only averaged indicators that often lack flexibility and context, but also data related to social roles, age, gender, place of residence, educational level, income level and more. A study of evaluating experience of public authorities' performance shows (Table 1) that different opportunities and threats in using polling data are relevant to different governance stakeholders, while different methods of raw data collection have proven to be more or less relevant to each of them. 


\section{Macrothink}

Journal of Public Administration and Governance

ISSN 2161-7104

2019, Vol. 9, No. 4

Table 1. Opportunities and threats of polling data implementation for good governance assessment

\begin{tabular}{|c|c|c|c|c|}
\hline $\begin{array}{c}\text { Good } \\
\text { governance } \\
\text { principle }\end{array}$ & $\begin{array}{c}\text { Source of } \\
\text { information }\end{array}$ & Opportunities & Threats & $\begin{array}{l}\text { Recommended } \\
\text { data collection } \\
\text { methods }\end{array}$ \\
\hline $\begin{array}{c}\text { Efficiency and } \\
\text { Effectiveness } \\
\text { Sound Financial } \\
\text { Management } \\
\text { Innovation and } \\
\text { Openness to } \\
\text { Change } \\
\text { Competence and } \\
\text { Capacity }\end{array}$ & $\begin{array}{c}\text { Public } \\
\text { authorities/civil } \\
\text { servants }\end{array}$ & $\begin{array}{c}\text { Flexibility and } \\
\text { operational } \\
\text { Efficiency of } \\
\text { information } \\
\text { Feedback basis } \\
\text { Legitimation of } \\
\text { managerial } \\
\text { decisions }\end{array}$ & $\begin{array}{l}\text { Possibility of } \\
\text { subjectivity } \\
\text { Danger of } \\
\text { vulnerability } \\
\text { under the } \\
\text { pressure of } \\
\text { public opinion } \\
\text { Evading a } \\
\text { questions }\end{array}$ & $\begin{array}{c}\text { Expert interview } \\
\text { Open-ended } \\
\text { survey }\end{array}$ \\
\hline $\begin{array}{l}\text { Human Rights, } \\
\text { Cultural } \\
\text { Diversity and } \\
\text { Social Cohesion } \\
\text { Rule of Law } \\
\text { Ethical Conduct } \\
\text { Responsiveness } \\
\text { Accountability }\end{array}$ & $\begin{array}{l}\text { Civil society } \\
\text { organizations }\end{array}$ & $\begin{array}{l}\text { Empirical data } \\
\text { for public } \\
\text { monitoring } \\
\text { Transparency } \\
\text { and public } \\
\text { integrity basis }\end{array}$ & $\begin{array}{l}\text { Vulnerability } \\
\text { under the } \\
\text { pressure of } \\
\text { business elites } \\
\text { Professional or } \\
\text { political } \\
\text { preconception }\end{array}$ & $\begin{array}{c}\text { Desk research } \\
\text { Expert } \\
\text { interviews }\end{array}$ \\
\hline $\begin{array}{l}\text { Sustainability } \\
\text { and Long-Term } \\
\text { Orientation } \\
\text { Participation, } \\
\text { Representation, } \\
\text { Fair Conduct of } \\
\text { Elections } \\
\text { Openness and } \\
\text { Transparency }\end{array}$ & Citizens & $\begin{array}{l}\text { Feedback basis } \\
\text { Public mood } \\
\text { monitoring } \\
\text { Additional tool } \\
\text { to put pressure } \\
\text { on the public } \\
\text { authorities } \\
\text { Instrument of } \\
\text { control } \\
\text { Transparency } \\
\text { and public } \\
\text { integrity basis }\end{array}$ & $\begin{array}{l}\text { Personal data } \\
\text { vulnerability } \\
\text { Evading a } \\
\text { questions }\end{array}$ & Opinion survey \\
\hline
\end{tabular}

Thus, representative quantitative data collection techniques (such as mass face-to-face surveys, online surveys etc.) are more appropriate for the largest group of stakeholders in the public administration system (citizens). While unique personal experience and functional literacy of representatives of public authorities or civil society organizations can be taken into account (and not lost in averaging data process) when using methods such as expert, in-depth interviews or desk research. While combining methods in good governance evaluation opens 
additional opportunities for researcher, integrating strength both of qualitative and quantitative research.

For example, when measuring the degree of implementation of the Openness and Transparency principle, collecting polling data from citizens allows to:

- establish feedback with society (measure the willingness to give a bribe or the degree of acceptance of such a tradition);

- carry out public mood monitoring to screen trends related to the prevalence of corruption in a given society;

- to put pressure on the public authorities by using polling data to conduct public monitoring or public expertise of authorities' activity with further disclosure of the results to attract the public;

- instrument of control (for example, survey methods are widely used in the educational system to identify "centers" of corruption by interviewing students about their corruption experience during training).

Polling methods find their particular relevance in countries with transition economies (such as Ukraine, Moldova and a number of other post-socialist countries), where the phenomenon of "custom corruption" is very common, and the act of corruption is so familiar to citizens that it is even perceived as a mechanism of interaction simplification with public authorities. It is almost impossible to identify such a phenomenon using only statistical data, while polling data can at least indirectly describe the diffusion of this phenomenon. An example of one of the most successful ways of polling data appliance to governance quality study is Corruption Perceptions Index, which is based, inter alia, on survey methods. This data collection strategy for studying such a comprehensive and multifaceted phenomenon as corruption allows to use all the opportunities that give us a survey method.

\section{Conclusion}

The capacity of polling data usage in order to determine the effectiveness of good governance principles implementation is very high as it is extremely difficult to overcome adverse effects in public administration without taking into account its human context, expressed in thoughts, comment or even emotions. This information is particularly vital for the development, justification and implementation of local socio-economic development strategies. Today statistical observations on many aspects of the exercise of state power are carried out systematically, while there is a lack of systematic sociological monitoring based on valid methodology. Even though representative sociological surveys are widely conducted, however, they have their limitations in good governance evaluation, which are largely related to the absence of open polling data banks not to mention the fact that obtained data not always reaches responsible executors.

\section{Areas for Further Study}

Prospects for further development of polling data usage are to develop specific methods, 
techniques and tools that allow to study the process of public administration modernization in great detail. Particular attention should also be paid to the question of operationalization (both theoretical and empirical) of the basic concepts that characterize this process. Further solutions also require finding ways to overcome the constraints associated with the nature and use of polling data: the use of tools that reduce the subjectivity of the data obtained, the creation of questionnaires that, on the one hand, could provide standardized information, and on the other, could take into account the specificities of each region or country.

\section{References}

12 Principles of Good Governance and European Label of Governance Excellence (ELoGE) (n.d) [Online]

Available: https://www.coe.int/en/web/good-governance/12-principles-and-eloge. (October 25, 2019).

Arndt, C., \& Oman, C. (2006). Uses and Abuses Of Governance Indicators. [Online] Available:

http://lst-iiep.iiep-unesco.org/cgi-bin/wwwi32.exe/[in=epidoc $1 . i n] / ? t 2000=022996 /(100)$. (November 4, 2019).

Bangura, Y., \& Larbi, G. (2006). Public Sector Reform in Developing Countries: Capacity Challenges to Improve Services. http://1st-iiep.iiep-unesco.org/cgi-bin/wwwi32.exe/[in=epidoc1.in]/?t2000=025533/(100). (September 27, 2019).

Berger, G. (2003). Reflections on Governance: Power Relations and Policy Making in Regional Sustainable Development. Journal of Environmental Policy \& Planning, 5(3), 219-234. https://doi.org/10.1080/1523908032000154160

Besancon, M. (2003). Good governance rankings: the art of measurement. World Peace Foundation Reports, 36, 11-34, Cambridge, Massachusetts.

Danylyshyn, B. (2016) Decentralization in EU countries: lessons for Ukraine. Regional economy, 1, 5-11.

den Heyer, G. (2011). New public management: A strategy for democratic police reform in transitioning and developing countries. Policing: An International Journal of Police Strategies \& Management, 34, 419-433. https://doi.org/10.1108/13639511111157492

Garbarino, S., \& Holland, J. (2009). Quantitative and Qualitative Methods in Impact Evaluation and Measuring Results. [Online] Available: http://www.gsdrc.org/docs/open/eirs4.pdf (November 4, 2019).

Graham, J., Amos, B., \& Plumptre, T. (2003). Principles for Good Governance in the 21st century. Policy Brief. Institute On Governance. 15. [Online] Available: https://www.files.ethz.ch/isn/122197/pa_governance2.pdf (November 28, 2019).

Guidance Note for Assessing Rule of Law in Public Administration. (2015). [Online] Available:

https://www.undp.org/content/dam/undp/library/Democratic\%20Governance/Public\%20Adm 
inistration/Assessing-Respect-for-Rule-of-Law-Guidance_note.pdf (October 5, 2019).

Huk, A. (2018). Benchmarkinh dobroho vryaduvannya: praktychnyy posibnyk [Good Governance Benchmarking: A Practical Guide]. Kyiv: Yuston. p.60.

Ivanyna, M., \& Shah, A. (2011). Citizen-centric governance indicators: measuring and monitoring governance by listening to the people. CESifo Forum, 1, 59-71.

Kaufmann, D., \& Kraay, A. (2008). Governance Indicators: Where Are We, Where Should We Be Going? The World Bank Research Observer, 23(1), 1-30. https://doi.org/10.1093/wbro/lkm012https://doi.org/10.1093/wbro/lkm012

Kaufmann, D., Kraay, A., \& Mastruzzi, M. (2006). Governance Matters V: Governance Indicators for 1996-2005. World Bank Policy Research Working Paper, 4012. [Online] Available: $\quad$ https://ssrn.com/abstract=930847 (November $25, \quad 2019$ ). https://doi.org/10.1596/1813-9450-3630

Kaufmann, D., Kraay, A., \& Zoido, P. (1999). Governance Matters. Policy Research Working Paper 2196. Washington, D.C.: The World Bank. p. 68.

Petry, F., \& Birch, L. (2011). The use of public opinion research by government: insights from American and Canadian Research. [Online] Available: https://www.researchgate.net/publication/256538643 The use of public opinion research by government insights from American and Canadian Research (November 4, 2019).

Rochefort, D., \& Boyer, C. (1988). Use of Public Opinion Data in Public Administration: Health Care Polls. Public administration review, 48, 649-60. https://doi.org/10.2307/975767

Sharma, P. K., \& Rathore, V. S. (2020). Performance Analysis of E-Governance Citizen-Centric Services Through E-Mitra in Rajasthan. In: Pant M., Sharma T., Basterrech S., Banerjee C. (Eds) Performance Management of Integrated Systems and its Applications in Software Engineering. Asset Analytics (Performance and Safety Management) (pp. 175-182). Singapore: Springer. https://doi.org/10.1007/978-981-13-8253-6_16

Shpachuk, V. (2019). Reform of the public administration system in Ukraine at the territorial level in the context of decentralization. In L. V. Honiukova, V. G. Hornyk, V. V. Karlova, S. O. Kravchenko (Eds.), Development of mechanisms of good governance in Ukraine (pp.88-121). Lviv-Toruń: Liha-Pres. https://doi.org/10.36059/978-966-397-114-8/88-121

Stojanovic, I., Ateljevic, J., \& Stević, S. (2016). Good Governance as a Tool of Sustainable Development. European Journal of Sustainable Development, 5, 558-573. http://dx.doi.org10.14207/ejsd.2016.v5n4p558. https://doi.org/10.14207/ejsd.2016.v5n4p558

Tampieri, L. (2005). Performance Evaluation Indexes in Public Administration Some issues of their actual usefulness. Central European Public Administration, 3(2), 59-82. https://doi.org/10.17573/cepar.v3i2.51https://doi.org/10.17573/cepar.v3i2.51

Vorobyova, O. (2015). Suchasni upravlins'ki modeli new public management i good governance ta yikh zaprovadzhennya v Ukrayini [Modern governance models of new public 
management and good governance and their implementation in Ukraine]. Efficiency of public governance, 42, 230-234.

Wijkman, A. (1998). Does sustainable development require good governance? UN Chronicl, 35(1), 86-88, Spring.

\section{Copyright Disclaimer}

Copyright for this article is retained by the author(s), with first publication rights granted to the journal.

This is an open-access article distributed under the terms and conditions of the Creative Commons Attribution license (http://creativecommons.org/licenses/by/4.0/). 